International Journal of Business Management and Economic Review

Vol. 4, No. 04; 2021

ISSN: 2581-4664

\title{
THE ROLE OF FINANCIAL LITERACY IN MEDIATION OF SOCIODEMOGRAPHIC EFFECTS ON INVESTMENT DECISIONS
}

\author{
I Putu Wahyu Putra Asmara and Luh Putu Wiagustini \\ Faculty of Economics and Business, Udayana University, Bali, Indonesia
}

http://doi.org/10.35409/IJBMER.2021.3289

\begin{abstract}
The purpose of this study is to analyze and explain the effect of sociodemographic on investment decisions, analyze and explain the influence of sociodemographic on financial literacy, analyze and explain the effect of financial literacy on investment decisions, analyze and explain the role of financial literacy in mediating the influence of sociodemographic on investment decisions. The population of this study are individuals who have or are currently investing in the Indonesia Stock Exchange. The sampling technique used was non-probability sampling with an accidental sampling approach. The number of samples in this study was 80 samples. Data was collected by distributing questionnaires using a 5-point Likert scale. The data analysis technique used is SEM-PLS. The results show that sociodemographic has a significant effect on investment decisions, financial literacy has a significant positive effect on investment decisions, financial literacy has a role as a partial mediator between sociodemographic on investment decisions. Partially, financial literacy has a role as a full mediator between education and investment decisions. Income, age, and gender have no direct or indirect effect on investment decisions.
\end{abstract}

Keyword: Investment Decision, Financial Literacy, Sociodemographic, Stocks, Investor.

\section{INTRODUCTION}

Investing in shares can be done in the Capital Market. The Capital Market in Indonesia is known as the Indonesia Stock Exchange (IDX). In stock investment, investors will lend the funds they have and will have ownership rights to companies that borrow funds, while companies that need funds will obtain loan funds from investors (Fahmi, 2011: 86). The advantage of investing in shares is that apart from getting ownership rights to the company, investors will also get a return on the company's shares owned. Stock returns are obtained from dividends and capital gains and capital losses. Stock investment is classified as an investment that is quite in demand in Indonesia. This is evidenced by the increase in Single Investor Identification (SID) throughout 2020.

Investors in investing in stocks will always be related to the theory of planned behavior and rational choice theory. The theory of planned behavior assumes that humans are rational beings and use the information that is possible for them systematically, the implications of an action before deciding to do or not to perform certain behaviors. Rational choice theory explains how to choose actions that can maximize utility, maximize profits and minimize risk. Every investment decision taken needs to be carried out by fundamental and technical analysis. Investors also need 


\section{International Journal of Business Management and Economic Review}

Vol. 4, No. 04; 2021

ISSN: 2581-4664

to pay attention to outstanding issues so that when there are bad issues, investors will be able to avoid the risks that may occur and when there are good issues investors will also be able to take advantage of the momentum to obtain possible profits from the shares concerned.

In relation to the theory of planned behavior and rational choice theory, knowledge, understanding and skills regarding financial concepts and risks are required in order not to make mistakes in making investment decisions. Knowledge and understanding of financial concepts and risks is commonly referred to as financial literacy (OECD, 2013). Financial literacy is knowledge and understanding of financial concepts and risks, and the skills, motivation and confidence to apply that knowledge and understanding to make effective decisions in various financial contexts, to improve individual financial well-being (Liebowitz, 2016:6). The Organization for Economic Co-operation and Development or OECD (2013) defines financial literacy as knowledge and understanding of financial concepts and risks, skills, motivation, and confidence to apply the knowledge and understanding they have in order to make effective financial decisions, improve welfare individual and community financial well-being, and participating in the economic field.

Financial literacy is not only important for households but also for the economy. According to Jappelli (2010) the benefits of financial literacy are grouped into three things, namely the benefits from the asset, debt, and macroeconomic aspects. On the asset side, financial literacy becomes important because of the presence of increasingly complex financial products. Low financial literacy can result in suboptimal risk diversification, inefficient portfolio allocation and low savings. From the debt side, loans in the mortgage market, credit card ownership and increased consumer credit can increase financial risk, while from a macro perspective, financial literacy contributes to markets and policies (Hidajat, 2015:6).

Based on the 2016 survey, the level of financial literacy of countries in Southeast Asia (ASEAN) is low when compared to the average of 17 OECD countries, 30 of which participated in the survey. Figure 1. will show the financial literacy scores of 17 OECD countries, 30 countries participating in the survey, as well as several ASEAN countries.

Financial knowledge score Financial behaviour score Financial attitude score

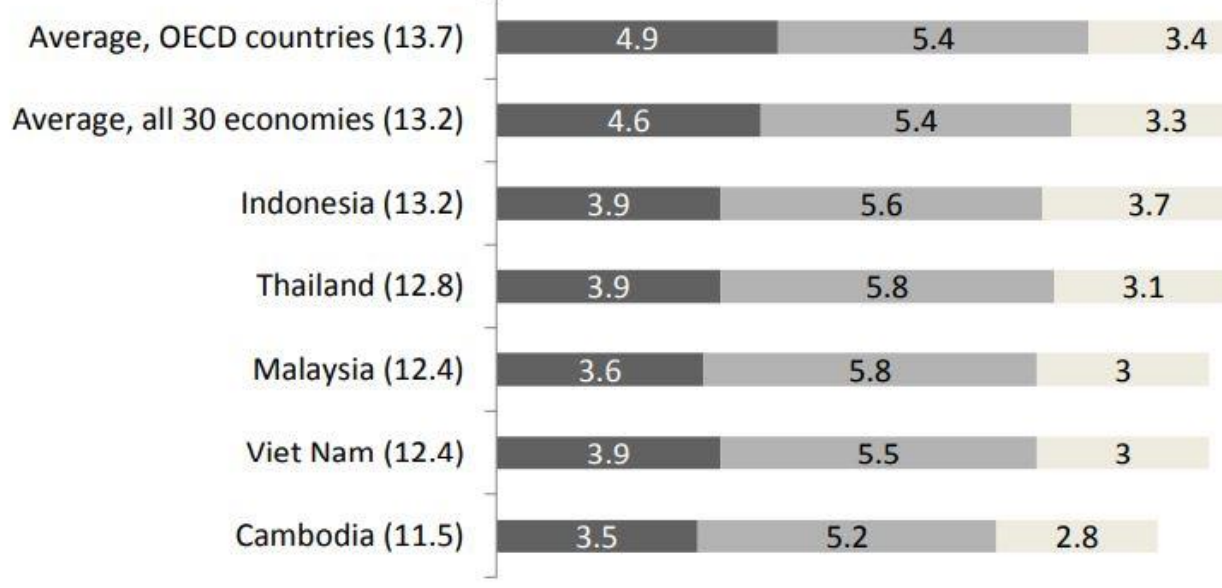

Figure 1. Financial Literacy Scores in Several ASEAN Countries 
International Journal of Business Management and Economic Review

Vol. 4, No. 04; 2021

ISSN: 2581-4664

Source: Organization for Economic Co-operation and Development (2018)

Figure 1 shows the financial literacy scores of the five ASEAN countries. Compared to the average of 17 OECD countries and 30 countries participating in the survey. Indonesia has the highest financial literacy score among the five countries that participated in the financial literacy survey, but the financial literacy score in these ASEAN countries is still relatively low when compared to the average of 17 OECD countries and 30 countries participating in the survey. These results indicate that financial literacy is of particular concern in the ASEAN region. Therefore, continuous efforts are needed to improve financial literacy.

Financial literacy has also become a national program so that people become financially literate and will ultimately increase the prosperity and welfare of the nation (Hidajat, 2015:1). The Financial Services Authority (OJK) and the financial services industry are currently intensively improving financial literacy and education, in addition, the President of the Republic of Indonesia has also published the National Strategy for Indonesian Financial Literacy (SNLKI 2013) which has now been refined to become the SNLKI (Revisit 2017). ) as part of the Trilogy of Policy Instruments in order to increase public trust and equality between consumers and the financial services industry (SNLKI Revisit, 2017:1).

There are several important factors that affect the level of financial literacy which later by having a good level of financial literacy will make individuals able to make wiser investment decisions. These factors include social, economic and demographic (Aprea et al., 2016:1), while according to OJK in the book National Strategy for Financial Literacy, external factors that have the potential to influence the success of financial literacy include economic growth, income per capita, income distribution, poverty level, education level, productive age group of the population, and utilization of information technology. There are many studies that conduct studies on factors that affect people's financial literacy, but in general the factors that affect financial literacy include income, age, gender, and education (Hidajat, 2015:14). These factors will be indicators of sociodemographic variables.

Sociodemographic is a combination of the words socioeconomic and demographic. Socioeconomic is a person's position in society related to other people in terms of the social environment, achievements, rights and obligations. Demographics is a description of a person's background that will be able to affect a person's level of financial literacy. Financial literacy will mediate between the influence of sociodemographic on investment decisions because there are still differences in research results between the direct effect of sociodemographic on investment decisions.

Research conducted by Alwahaibi (2019), Dewi and Purbawangsa (2018), Faidah (2019), Arianti (2018), Violeta and Linawati (2019) examines the effect of sociodemographic income on investment decisions. They found that income had a significant positive effect on investment decisions. Research conducted by Putri and Isbanah (2020), Putri and Rahyuda (2017), Rahman and Gan (2020) actually found that income had no effect on investment decisions. Alwahaibi (2019), Bhavani and Shetty (2017), Santoso et al (2015), Violeta and Linawati (2019) also conducted tests to examine the effect of sociodemographic age on investment decisions. They found results that age had a significant effect on investment decisions, while research conducted by Aren and Aydemir (2015), Putri and Isbanah (2020) obtained the opposite result which stated that age had no effect on investment decisions. 


\section{International Journal of Business Management and Economic Review}

Vol. 4, No. 04; 2021

ISSN: 2581-4664

Joseph (2015), Mahapatra and Mehta (2015), Putri and Rahyuda (2017), Santoso et al (2015), Violeta and Linawati (2019) examined the effect of gender on investment decisions and found that gender had a significant effect on investment decisions. . Research conducted by Putri and Isbanah (2020), Rahman and Gan (2020) obtained the opposite result which stated that gender had no effect on investment decisions. Sociodemographic of education also experienced inconsistency of research results. Bhavani and Shetty (2017), Tanusdjaja (2018) found that education has a significant positive effect on investment decisions. Putri and Isbanah (2020), Santoso et al (2015) actually obtained results which stated that education had no effect on investment decisions.

The difference in research results between the direct influence of sociodemographic on investment decisions makes financial literacy an important variable that will help sociodemographics consisting of income, age, gender and education in influencing investment decisions. Income is the amount obtained after providing goods or services to consumers. Individuals who have a high income level are more likely to use financial instruments and services so that they will tend to have a higher level of financial literacy which will later be able to make individuals able to make the right investment decisions. Low-income individuals are more likely to be due to drop out of school, something that in the long run causes financial blindness (Calamato, 2010). Research conducted by Akmal and Saputra (2016), Ali et al., (2016), Andansari (2017), Chetanbhai et al., (2018), Jana et al., (2019), Janor et al., (2016 ), Lestari (2020), Natoli (2018), Sofia and Irianto (2016), Wiharno (2015) found that income levels have a significant positive effect on financial literacy.

Standard procedures such as electronic payments, which have replaced face-to-face transactions, require knowledge and skills related to finance. Adolescents and early adults are more likely to have to bear more of the financial risk than their parents because they are consumers of financial services from a young age such as online payments, cell phones, and other technologies (Aprea et al., 2016:2). Teenagers and early adults who have a higher level of financial literacy will be able to make the right investment decisions. There are several studies that support this theory. Akoto et al (2017), Aribawa and Widyatini (2017), Garg and Singh (2017), Loke (2017), Margaretha and Pembudhi (2015), Mouna and Anis (2016), Yoshino et al., (2017) found that age has a significant effect on financial literacy.

Gender will also affect a person's literacy level. According to Hidajat (2015: 18) most of the research results state that the level of financial literacy of men is higher than that of women. Men as the successors of the offspring and also as the head of the household, with the main task as breadwinners for their family life, carrying out their duties, obligations, and responsibilities, are mostly carried out outside the home so that the level of financial literacy of men will be higher than women, so that with a higher level of financial literacy than women, men will be able to make the right investment decisions. Edwards et al., (2007) concluded that parents have different expectations of boys and girls, because they have higher expectations about work and savings for boys, so they are more likely to talk to boys. . Research conducted by Adam et al., (2017), Ahmadi and Sulistyowati (2018), Ergun (2018), Febriyani and Sari (2017), Grohmann (2016), Margaretha and Pembudhi (2015), Potrich et al., (2017 ), Vijayvargy and Bakhshi (2018), Wijayanti et al., (2016), Yunita (2020) found that gender has a significant effect on a person's financial literacy.

A person's education will affect the level of literacy they have. According to Hidajat (2015: 18) 


\section{International Journal of Business Management and Economic Review}

Vol. 4, No. 04; 2021

ISSN: 2581-4664

states that someone who has a high level of education, especially in business programs will have a better level of financial literacy. Financial products and service utility are positively correlated with a person's level of education. According to OJK in the book National Strategy for Financial Literacy, people with higher education on average use two to three financial products and services. The higher a person's education, the more knowledge they have, especially in the field of finance so that they will have a higher level of financial literacy. Individuals who have a higher level of financial literacy will certainly better understand the concepts, risks regarding financial products and instruments so that they will be able to make the right investment decisions. According to Bhushan and Medury (2013), a higher level of education will increase the level of income which will affect financial literacy. Research conducted by Ghazali et al., (2017), Hasan (2017), Jacobsen Correia (2019), Prasad et al., (2018), Son and Park (2019), Stella et al., (2020), Shafik and Ahmad (2019), Syuliswati (2020), Winstanley et al., (2018), Xiao and O'Neill (2016), Zhang and Xiong (2019) found that education level had a significant positive effect on a person's level of financial literacy.

\section{LITERATURE REVIEW AND HYPOTHESES DEVELOPMENT}

Just like the theory of planned behavior and rational choice theory, it assumes that humans are rational beings and use information and the implications of an action to maximize utility, maximize profits and minimize risk. Financial literacy is knowledge and information in a financial context that can be utilized by investors in investing in stocks so that investors will be able to maximize profits and minimize risk. Investors who have a good level of financial literacy will be able to manage their finances. The income earned every month will always be allocated as best as possible. Every need that is owned is always made a percentage so that you can still set aside the money you have for savings or investment.

According to SNLKI Revisit (2017:77), financial literacy is knowledge, skills, and beliefs that influence attitudes and behavior to improve the quality of decision making and financial management in order to achieve prosperity so that the ability and understanding of good financial literacy will greatly assist the community in understanding and knowing the concepts and financial risks that will enable individuals to make wiser investment decisions. Understanding good financial literacy can help someone in determining investment decisions with the maximum rate of return. This theory is supported by research conducted by Abdeldayem (2016), Awais et al., (2016), Dewi and Purbawangsa (2018), Khairiyati and Krisnawati (2019), Putri and Hamidi (2019), Sabri (2016), Upadana and Herawati (2020) which states that financial literacy has a significant positive effect on investment decisions so that the following hypothesis can be formulated.

H1 = Financial Literacy has a positive effect on Investment Decisions

planned behavior and Rational choice theory. The theory of planned behavior and Rational choice theory which assumes that humans are rational beings and use the information and implications of an action that can maximize utility, maximize profits and minimize risk. The theory of planned behavior and Rational choice theory are closely related to the sociodemographic effects of income, age, gender, and education. Income has an effect on investment decisions. The higher the education, the higher a person's income so that they will have better investment decisions. Individuals with high incomes tend to have invested and have more knowledge, while individuals with low incomes tend to find it difficult to invest because 


\section{International Journal of Business Management and Economic Review}

Vol. 4, No. 04; 2021

ISSN: 2581-4664

their income is limited to meet their daily needs (Violeta and Linawati, 2019). This knowledge is one source of information that can be used to maximize profits and minimize risks in investing. Akims and Jagongo (2017) stated that age has an influence on investment decisions. Individuals who are in their productive age will think more about investing by buying an asset for the future. The productive age will always look for information that can be used to maximize profits and minimize risks.

Gender will also be able to influence a person's investment decisions. Men are more willing to take risks and avoid more risks than women. Male investors invest money based on the prospect of return and risk. Expectations of higher returns motivate people to take more risks (Mahapatra and Mehta, 2015). Men have a higher level of self-confidence than women. This indicates that the gender factor is also one of the causes of the behavior of individuals who dare to take risks Joseph (2015). Men who are more daring in taking risks and avoiding risk and having more expected returns will motivate male investors to take more risks and seek information that can maximize profits in investing in stocks. It's the same as the concept

The theory of planned behavior and Rational choice theory are also related to the influence of one's education on an investor's investment decision. Investors with a higher educational background have higher competence, more knowledge about stock movements and are more daring in taking risks so that their decision making in investing is better than investors with lower education (Joseph, 2015).

This theory is supported by research conducted by Alwahaibi (2019), Dewi and Purbawangsa (2018), Faidah (2019), Fitriarianti (2018), Violeta and Linawati (2019) which found that income had a significant positive effect on investment decisions. Alwahaibi (2019), Bhavani and Shetty (2017), Santoso et al (2015), Violeta and Linawati (2019) found that age had a significant positive effect on investment decisions. Joseph (2015), Mahapatra and Mehta (2015), Putri and Rahyuda (2017), Santoso et al (2015) who obtained the results that men have a significant positive effect on investment decisions. Bhavani and Shetty (2017), Tanusdjaja (2018) who get the results that education has a significant positive effect on investment decisions.

$\mathrm{H} 2=$ Sociodemographic has an effect on investment decisions.

$\mathrm{H} 2 \mathrm{a}=$ Income has a significant positive effect on investment decisions

$\mathrm{H} 2 \mathrm{~b}=$ Adolescence and early adulthood have a significant positive effect on investment decisions $\mathrm{H} 2 \mathrm{c}=$ Men have a significant positive effect on investment decisions $\mathrm{H} 2 \mathrm{~d}=$ Education has a significant positive effect on investment decisions

Individuals who have a high level of income are more likely to use financial instruments and services so they will tend to have a higher level of financial literacy. Standard procedures such as electronic payments, which have replaced face-to-face transactions, require knowledge and skills related to finance. Adolescents and early adults are more likely to have to bear more of the financial risk than their parents because they are consumers of financial services from a young age such as online payments, cell phones, and other technologies (Aprea et al., 2016:2).

Men as the successors of the offspring and also as the head of the household, with the main task as breadwinners for their family life, carrying out their duties, obligations, and responsibilities, are mostly carried out outside the home so that the level of financial literacy of men will be higher than women., resulting in a higher level of financial literacy than women. According to OJK in the book National Strategy for Financial Literacy, people with higher education on average use two to three financial products and services. Individuals who have a good level of 


\section{International Journal of Business Management and Economic Review}

Vol. 4, No. 04; 2021

ISSN: 2581-4664

financial literacy will better understand concepts, risks regarding financial products and instruments.

This theory is supported by research conducted by Ali et al., (2016), Andansari (2017), Chetanbhai et al., (2018), Jana et al., (2019), Janor et al., (2016), Lestari (2020), Natoli (2018), Wiharno (2015) who found that income had a significant positive effect on financial literacy. Akoto et al (2017), Garg and Singh (2017), Loke (2017), Margaretha and Pembudhi (2015), Mouna and Anis (2016), Yoshino et al., (2017) obtained the results that age had a significant positive effect on literacy finance. Adam et al., (2017), Ergun (2018), Erner et al., (2016), Potrich et al., (2017), Vijayvargy and Bakhshi (2018), Wijayanti et al., (2016), Yunita (2020) which shows that male has a significant positive effect on financial literacy. Ghazali et al., (2017), Hasan (2017), Jacobsen Correia (2019), Potrich et al., (2015), Prasad et al., (2018), Son and Park (2019), Stella et al., (2020), Shafik and Ahmad (2019), Winstanley et al., (2018), Xiao and O'Neill (2016), Zhang and Xiong (2019) which obtained the results that education had a significant positive effect on financial literacy.

$\mathrm{H} 3=$ Sociodemographic affects financial literacy

$\mathrm{H} 3 \mathrm{a}=$ Income has a significant positive effect on financial literacy

$\mathrm{H} 3 \mathrm{~b}=$ Adolescence and early adulthood have a significant positive effect on financial literacy

$\mathrm{H} 3 \mathrm{c}=$ Male has a significant positive effect on financial literacy

$\mathrm{H} 3 \mathrm{~d}=$ Education has a significant positive effect on financial literacy

Financial literacy which mediates sociodemographic influence on investment decisions is closely related to Theory of planned behavior and Rational choice theory because investors will be able to get information and implications of actions that will maximize profits and reduce risks. Financial literacy is knowledge and information in a financial context that can be utilized by investors in investing in stocks so that investors will be able to maximize profits and minimize risk. Individuals who have a high level of income are more likely to use financial instruments and services so that they will tend to have a higher level of financial literacy which will later be able to make individuals able to make better investment decisions. Standard procedures such as electronic payments, which have replaced face-to-face transactions, require knowledge and skills related to finance. Adolescents and early adults are more likely to have to bear more of the financial risk than their parents because they are consumers of financial services from a young age such as online payments, cell phones, and other technologies (Aprea et al., 2016:2). Teenagers and early adults who have a higher level of financial literacy will be able to make better investment decisions.

Men as the successors of the offspring and also as the head of the household, with the main task as breadwinners for their family life, carrying out their duties, obligations, and responsibilities, are mostly carried out outside the home so that the level of financial literacy of men will be higher than women., so that with a higher level of financial literacy than women, men will be able to make better investment decisions. According to OJK in the book National Strategy for Financial Literacy, people with higher education on average use two to three financial products and services. Individuals who have a higher level of financial literacy will certainly have a better understanding of concepts, risks regarding financial products and instruments so that they will be able to make wiser investment decisions.

This theory is supported by research conducted by Ali et al., (2016), Andansari (2017), Chetanbhai et al., (2018), Jana et al., (2019), Janor et al., (2016), Lestari (2020), Natoli (2018), 


\section{International Journal of Business Management and Economic Review}

Vol. 4, No. 04; 2021

ISSN: 2581-4664

Wiharno (2015) who found that income had a significant positive effect on financial literacy. Akoto et al (2017), Garg and Singh (2017), Loke (2017), Margaretha and Pembudhi (2015), Mouna and Anis (2016), Yoshino et al., (2017) obtained the results that age had a significant positive effect on literacy finance. Adam et al., (2017), Ergun (2018), Erner et al., (2016), Potrich et al., (2017), Vijayvargy and Bakhshi (2018), Wijayanti et al., (2016), Yunita (2020) which shows that male has a significant positive effect on financial literacy.

Ghazali et al., (2017), Hasan (2017), Jacobsen Correia (2019), Potrich et al., (2015), Prasad et al., (2018), Son and Park (2019), Stella et al., (2020), Shafik and Ahmad (2019), Winstanley et al., (2018), Xiao and O'Neill (2016), Zhang and Xiong (2019) which obtained the results that education had a significant positive effect on financial literacy. Research conducted by Abdeldayem (2016), Awais et al., (2016), Dewi and Purbawangsa (2018), Khairiyati and Krisnawati (2019), Putri and Hamidi (2019), Sabri (2016), Upadana and Herawati (2020) also supports the theory by obtaining research results which state that financial literacy has a significant effect on investment decisions, so the hypothesis can be formulated as follows.

H4 = Financial Literacy mediates the influence of sociodemographic on investment decisions

$\mathrm{H} 4 \mathrm{a}=$ Financial Literacy mediates the effect of income on investment decisions

$\mathrm{H} 4 \mathrm{~b}=$ Financial Literacy mediates the effect of age on investment decisions

$\mathrm{H} 4 \mathrm{c}=$ Financial Literacy mediates the effect of gender on investment decisions

$\mathrm{H} 4 \mathrm{~d}=$ Financial Literacy mediates the effect of education on investment decisions

\section{METHODS}

The research location is a place or area where the research will be carried out. The location of this research is in Indonesia. The subjects in this study are individuals who have or are currently investing in shares on the Indonesia Stock Exchange. The object studied in this study is investment decisions.

The population of this study are individuals who have or are currently investing in the Indonesia Stock Exchange. The total population cannot be counted (infinite population). The sampling technique used was non-probability sampling with an accidental sampling approach. Accidental sampling is a sampling technique based on chance, namely respondents who coincidentally meet with researchers who can be used as samples because they are considered suitable as data sources. The considerations used in sampling are individuals who have worked and have or are currently investing in shares on the Indonesia Stock Exchange.

The size of the number of samples studied is based on the opinion of Sekaran and Bougie (2016) who say that in survey research the sample size used should be 10x or more than the number of research variables/dimensions/indicators. Based on this statement, there are eight variable dimensions, which consist of four dimensions of sociodemographic variables (income, age, gender, education), three dimensions of financial literacy variables (Financial Attitudes, Financial Behavior, Financial Knowledge) and one dependent variable, then with reference to Based on the theory of determining the sample by Sekaran and Bougie (2016), the number of samples in this study is $8 \times 10=80$ samples.

Inferential statistics is a technique used to analyze sample data whose results will be applied to the study population. To test the hypothesis and produce a feasible model, this study uses Structural Equation Modeling (SEM) with the Partial Least Square (PLS) approach, which is operated with the help of SmartPLS software. 
International Journal of Business Management and Economic Review

Vol. 4, No. 04; 2021

ISSN: 2581-4664

\section{RESULT AND DISCUSSION}

There are three criteria in the use of data analysis techniques with Smart PLS to assess the outer model, namely Convergent Validity, Discriminant Validity, and Composite Reliability.

\section{Convergent Validity}

Convergent Validity can be seen from the Average Variance Extracted (AVE) value for each variable. In Table 1 it can be seen that each sociodemographic variable, financial literacy, and investment decision has an Average Variance Extracted (AVE) value of more than 0.5. Based on the test results, all variables have met the convergent validity requirements, so it can be concluded that all indicators are valid and feasible indicators to be able to measure their respective variables.

Table 1. Average Variance Extracted Research Variables

\begin{tabular}{lc}
\hline \multicolumn{1}{c}{ Variable } & Average Variance Extracted (AVE) \\
\hline Investment Decision $(\mathrm{Y})$ & 0,842 \\
\hline Financial Literacy $(\mathrm{M})$ & 0,709 \\
\hline Sociodemographic $(\mathrm{X})$ & 0,698 \\
\hline
\end{tabular}

Primary Data, 2021

1. Discriminant Validity

The measurement of reflexive indicators is based on cross loading with latent variables. Another model by comparing the value of the Square Root of Average Extracted (AVE) of each construct with the correlation between other constructs in the model. If the initial measurement values of the two models are better than the values of the other constructs in the model, it can be concluded that the construct has a good discriminant validity value or vice versa. Accordingly, it is recommended that the measurement value should be greater than 0.50. Table 5.9 shows that the value of the square root of the AVE $(0.842 ; 0.918 ; 0.836)$ is greater than the correlation of each construct, so it can be concluded that the model has no problem in terms of discriminant validity.

Table 2.Discriminant Validity

\begin{tabular}{lccc}
\hline & $\begin{array}{l}\text { Financial Literacy } \\
(\mathrm{M})\end{array}$ & $\begin{array}{c}\text { Investment Decision } \\
(\mathrm{Y})\end{array}$ & $\begin{array}{c}\text { Sociodemographic } \\
(\mathrm{X})\end{array}$ \\
\hline Financial Literacy $(\mathrm{M})$ & $\mathbf{0 , 8 4 2}$ & & \\
\hline $\begin{array}{l}\text { Investment Decision } \\
(\mathrm{Y})\end{array}$ & $\mathbf{0 , 9 6 3}$ & $\mathbf{0 , 9 1 8}$ & \\
\hline Sociodemographic $(\mathrm{X})$ & $\mathbf{0 , 8 0 6}$ & $\mathbf{0 , 7 4 1}$ & $\mathbf{0 , 8 3 6}$ \\
\hline
\end{tabular}

Primary Data, 2021

\section{Composite Reliability}

Reliability is a tool to measure a questionnaire which is an indicator of a variable or construct (Ghozali, 2016). A questionnaire is said to be reliable or reliable if a person's answer to the 


\section{International Journal of Business Management and Economic Review}

Vol. 4, No. 04; 2021

ISSN: 2581-4664

statement is consistent or stable from time to time. Respondents' answers to this question are said to be reliable if each question is answered consistently or the answers cannot be random because each question wants to measure the same thing. The measurement is said to be unreliable if the answer to the indicator is random. (Ghozali, 2016). To determine the reliability of the construct of a measurement model can be seen by using the value of composite reliability and the value of Cronbach's Alpha. The results of the measurement model reliability test are presented in Table 3. Based on the composite reliability and Cronbach's Alpha values presented in Table 5.10, each variable obtained measurement results with values above 0.70 . Thus, the measurement model in this study has good reliability on each of the variables.

\section{Table 3.Composite Reliability Coefficient and Cronbach's Alpha}

\begin{tabular}{lccc}
\hline Variable & Cronbach's Alpha & Composite Reliability & Description \\
\hline Investment Decision (Y) & 0,953 & 0,964 & Reliable \\
\hline Financial Literacy (M) & 0,991 & 0,992 & Reliable \\
\hline Sociodemographic (X) & 0,851 & 0,900 & Reliable \\
\hline Prioder
\end{tabular}

Primary Data, 2021

Structural Model Testing (Inner Model)

Testing of the inner model or structural model is carried out to see the relationship between the variables, the significance value and the R-Square of the research model. Evaluation of the structural model or inner model is carried out to ensure that the structural model built is robust and accurate. The test can be done by calculating the value of $\mathrm{R}$ square and predictive relevance (Q2).

\section{R-Square ( $\left.\mathbf{R}^{2}\right)$}

Shows the strength and weakness of the influence caused by variations in exogenous variables on endogenous variables. The R-Square (R2) value greater than 0.50 is categorized as a strong model. The value of R-Square (R2) for each endogenous variable is presented in Table 4.

Table 4. Value of R-Square (R2) Endogenous Variable

\begin{tabular}{lcc}
\hline Variable & R Square & Description \\
\hline Sociodemographic $(\mathrm{X})$ & - & - \\
\hline Financial Literacy $(\mathrm{M})$ & 0,649 & Strong \\
\hline Investment Decision $(\mathrm{Y})$ & 0,931 & Strong \\
\hline Pring
\end{tabular}

Primary Data, 2021

Table 4 shows that the R-Square (R2) value of all variables is more than 0.50 so that it is included in the strong criteria, it can be said that the model formed is considered strong enough.

1. Q-Square (Predictive Relevance)

Q-Square (Predictive Relevance) measures how well the observed values produced by the estimation model and its parameters are. Q-Square value > 0 indicates the model has good 


\section{International Journal of Business Management and Economic Review}

Vol. 4, No. 04; 2021

ISSN: 2581-4664

predictive relevance. The value of Q-Square (Predictive Relevance) can be calculated as follows.

$$
\begin{aligned}
& \mathrm{Q} 2=1-\left(1-\mathrm{R}^{2} 1\right)\left(1-\mathrm{R}^{2} 2\right) \\
& \mathrm{Q} 2=1-(1-0,649)(1-0,931) \\
& \mathrm{Q} 2=1-(0,351)(0,069) \\
& \mathrm{Q} 2=1-(0,024) \\
& \mathrm{Q} 2=0,976 \text { or } 97,6 \%
\end{aligned}
$$

Calculation of Q-Square (Predictive Relevance) produces a value of 97.6\% which means that the model has a very good value. This means that $97.6 \%$ of the relationship between variables can be explained by the model while the remaining $2.4 \%$ is explained by other variables outside the model. Based on the results of the calculations above R2 and Q2, it can be continued with the analysis of hypothesis testing

Hypothesis test

\section{Direct Effects}

The existence of significance in the estimated parameters can be used to see the relationship between variables in the study. For hypothesis testing, it is done by looking at the

\begin{tabular}{|c|c|c|c|c|c|}
\hline & Coefficient & $\begin{array}{c}\text { Sample } \\
\text { Mean }(\mathbf{M}) \\
\end{array}$ & $\begin{array}{c}\text { Standard Deviation } \\
\text { (STDEV) }\end{array}$ & $\begin{array}{c}\text { T Statistics } \\
(\mid \text { O/STDEV } \mid)\end{array}$ & P Values \\
\hline $\mathbf{M}-\mathbf{Y}$ & 1,043 & 1,044 & 0,043 & 24,460 & 0,000 \\
\hline $\mathbf{X}-\mathbf{Y}$ & $-0,099$ & $-0,101$ & 0,048 & 2,072 & 0,039 \\
\hline $\mathbf{X}-\mathbf{M}$ & 0,806 & 0,802 & 0,053 & 15,089 & 0,000 \\
\hline X.1 - Y & $-0,021$ & $-0,017$ & 0,052 & 0,412 & 0,680 \\
\hline $\mathbf{X . 1}-\mathbf{M}$ & 0,151 & 0,146 & 0,126 & 1,197 & $\mathbf{0 , 2 3 2}$ \\
\hline $\mathbf{X . 2}-\mathbf{Y}$ & 0,003 & 0,003 & 0,045 & 0,077 & $\mathbf{0 , 9 3 9}$ \\
\hline X.2-M & 0,150 & 0,140 & 0,116 & 1,293 & 0,197 \\
\hline $\mathbf{X . 3}-\mathbf{Y}$ & $-0,066$ & $-0,065$ & 0,036 & 1,856 & 0,064 \\
\hline $\mathbf{X . 3 - M}$ & $-0,024$ & $-0,027$ & 0,074 & 0,330 & 0,741 \\
\hline $\mathbf{X . 4}-\mathbf{Y}$ & $-0,034$ & $-0,043$ & 0,067 & 0,515 & 0,607 \\
\hline X.4-M & 0,590 & 0,602 & 0,130 & 4,524 & 0,000 \\
\hline
\end{tabular}
value of the path coefficients presented in Table 5. Hypothesis testing is evaluated by looking at the p-value. P-value is less than 0.05 , then the research hypothesis can be accepted.

Table 5.

Path Coefficients

Primary Data, 2021

Information:

$\mathrm{Y}=$ Investment Decision

$\mathrm{M}=$ Financial Literacy

$\mathrm{X}=$ Sociodemographic

$\mathrm{X} .1$ = Revenue 


\section{International Journal of Business Management and Economic Review}

Vol. 4, No. 04; 2021

ISSN: 2581-4664

$$
\begin{aligned}
& \text { X.2 }=\text { Age } \\
& \text { X.3 }=\text { Gender } \\
& \text { X.4 }=\text { Education }
\end{aligned}
$$

Based on Table 5, it is known that the effect of financial literacy (M) on investment decisions (Y) has a coefficient value of 1.043 and a p-value of 0.000 . Because the coefficient value is positive and the p-value is less than 0.05 then $\mathrm{H} 3$ is accepted, so it can be concluded that financial literacy $(\mathrm{M})$ has a significant positive effect on investment decisions $(\mathrm{Y})$. The influence of sociodemographic $(\mathrm{X})$ on investment decisions $(\mathrm{Y})$ has a $\mathrm{p}$-value of 0.039 . Because the $\mathrm{p}$ value is less than $0.05, \mathrm{H} 1$ is accepted so that it can be concluded that sociodemographic (X) has a significant effect on investment decisions $(\mathrm{Y})$. The influence of sociodemographic (X) on financial literacy (M) has a p-value of 0.000 . Because the p-value is less than $0.05, \mathrm{H} 2$ is accepted, so it can be concluded that sociodemographic (X) has a significant effect on financial literacy $(\mathrm{M})$.

Partially the influence of sociodemographic income (X.1) on investment decisions (Y) has a $\mathrm{p}$-value of 0.680 . Because the $\mathrm{p}$-value is more than 0.05 , partially sociodemographic income (X.1) has no effect on investment decisions (Y). The influence of sociodemographic age (X.2) on investment decisions $(\mathrm{Y})$ has a p-value of 0.939. Because the p-value is more than 0.05 , partially sociodemographic age (X.2) has no effect on investment decisions (Y).

The influence of sociodemographic gender (X.3) on investment decisions $(\mathrm{Y})$ has a pvalue of 0.064 . Because the p-value is more than 0.05 , partially sociodemographic gender (X.3) has no effect on investment decisions (Y). The influence of sociodemographic education (X.4) on investment decisions $(\mathrm{Y})$ has a p-value of 0.607. Because the $\mathrm{p}$-value is more than 0.05 , partially sociodemographic education (X.4) has no effect on investment decisions (Y).

Partially the influence of sociodemographic income (X.1) on financial literacy (M) has a $\mathrm{p}$-value of 0.232 . Because the $\mathrm{p}$-value is more than 0.05 , partially sociodemographic income (X.1) has no effect on financial literacy (M). The effect of sociodemographic age (X.2) partially on financial literacy $(\mathrm{M})$ has a p-value of 0.197 . Because the $\mathrm{p}$-value is more than 0.05 , partially sociodemographic age (X.2) has no effect on financial literacy (M). The influence of sociodemographic gender (X.3) partially on financial literacy (M) has a p-value of 0.741 . Because the p-value is more than 0.05 , partially sociodemographic age (X.3) has no effect on financial literacy (M). The influence of sociodemographic education (X.4) partially on financial literacy $(\mathrm{M})$ has a p-value of 0.00 . Because the $\mathrm{p}$-value is less than 0.05 , partially sociodemographic education (X.4) has a significant effect on financial literacy (M).

\section{Indirect Effect}

This analysis aims to determine the significance of the indirect relationship between sociodemographic variables on investment decisions mediated by financial literacy variables. The results of the analysis are presented in table 6 . 
International Journal of Business Management and Economic Review

Vol. 4, No. 04; 2021

ISSN: 2581-4664

Table 6. Indirect Effect

\begin{tabular}{lccccc}
\hline Coefficient & $\begin{array}{c}\text { Sample } \\
\text { Mean (M) }\end{array}$ & $\begin{array}{c}\text { Standard } \\
\text { Deviation } \\
(\text { STDEV })\end{array}$ & $\begin{array}{c}\text { T Statistics } \\
(\mid \mathbf{O} \text { STDEV } \mid)\end{array}$ & P Values \\
\hline $\mathbf{X}-\mathbf{M}-\mathbf{Y}$ & 0,841 & 0,839 & 0,077 & 10,945 & $\mathbf{0 , 0 0 0}$ \\
\hline $\mathbf{X . 1}-\mathbf{M}-\mathbf{Y}$ & 0,155 & 0,151 & 0,131 & 1,189 & $\mathbf{0 , 2 3 5}$ \\
\hline $\mathbf{X . 2}-\mathbf{M}-\mathbf{Y}$ & 0,154 & 0,144 & 0,119 & 1,295 & $\mathbf{0 , 1 9 6}$ \\
\hline $\mathbf{X . 3}-\mathbf{M}-\mathbf{Y}$ & $-0,025$ & $-0,028$ & 0,076 & 0,331 & $\mathbf{0 , 7 4 1}$ \\
\hline $\mathbf{X . 4}-\mathbf{M}-\mathbf{Y}$ & 0,606 & 0,622 & 0,144 & 4,217 & $\mathbf{0 , 0 0 0}$ \\
\hline
\end{tabular}

Primary Data, 2021

Based on Table 6, the results of t-value the indirect effect of sociodemographic variables on investment decisions are 10.945 and p-values are 0.000. Because p-values are less than 0.05 , $\mathrm{H} 1$ is accepted. These results indicate that there is an indirect relationship between sociodemographic variables and investment decisions mediated by financial literacy.

Partially, the results of t-value the indirect effect of sociodemographic income on investment decisions are 1.189 and p-values are 0.235 . Because the p-values are more than 0.05 , these results show that financial literacy is partially unable to mediate the sociodemographic influence of income on investment decisions.

The result of t-value the indirect effect of sociodemographic age on investment decisions is 1.295 and p-values are 0.196. Because p-values are more than 0.05 , these results indicate that financial literacy is partially unable to mediate the influence of sociodemographic age on investment decisions.

The results of t-value the indirect effect of gender sociodemographic on investment decisions are 0.331 and $p$-values are 0.741 . Because $p$-values are more than 0.05 , these results indicate that financial literacy is partially unable to mediate the influence of sociodemographic gender on investment decisions.

The result of t-value the indirect influence of sociodemographic education on investment decisions is 4.217 and p-values are 0.00 . Because p-values are more than 0.05 , these results indicate that there is an indirect relationship between sociodemographic education and investment decisions mediated by financial literacy. 
International Journal of Business Management and Economic Review

Vol. 4, No. 04; 2021

ISSN: 2581-4664

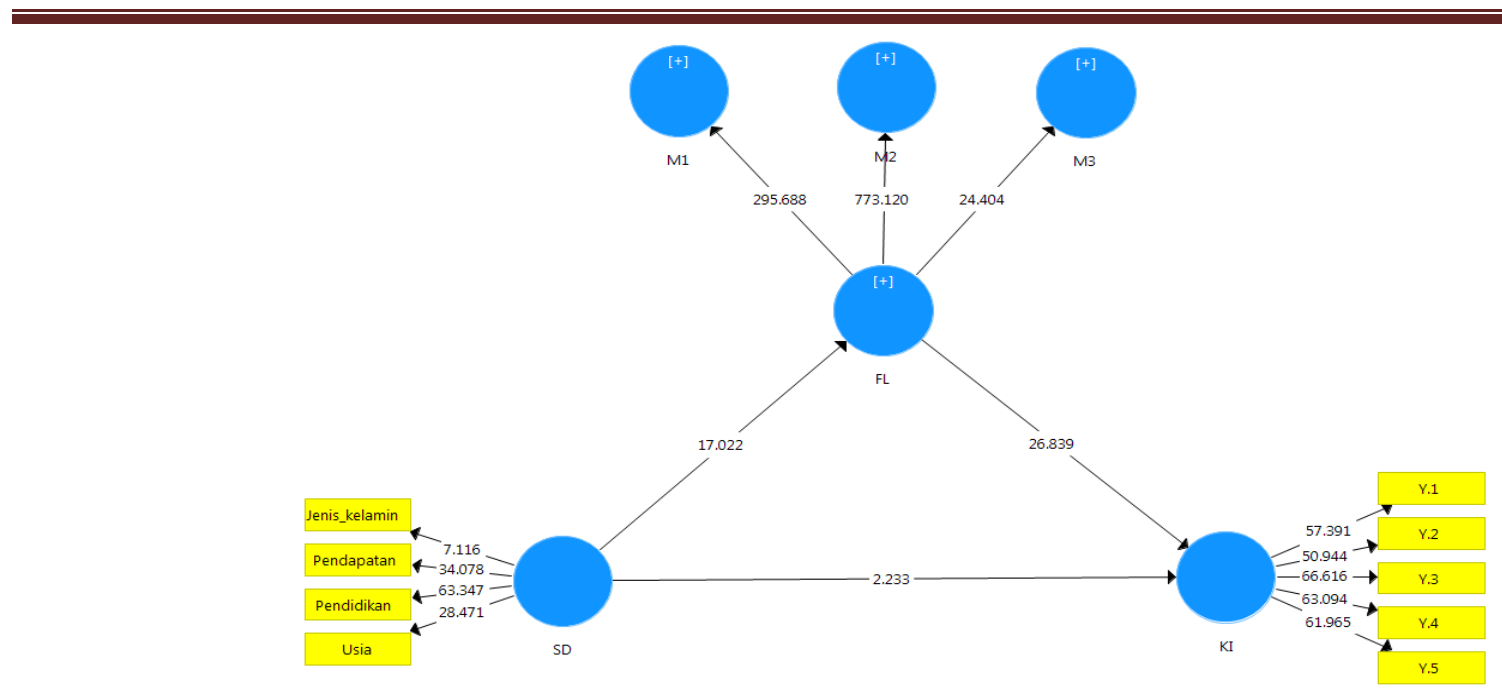

Figure 2. Path Diagram of SEM-PLS

\section{CONCLUSION}

Financial Literacy in mediating the influence of sociodemographic on investment decisions. The results of this study can also provide empirical evidence that sociodemographic effect investment decisions mediated by financial literacy. In addition, this research can also contribute to the science of financial management, especially about the factors that influence investment decisions made by stock investors. Sociodemographic conditions of investors as well as a good level of financial literacy will result in stock investors having effective investment decisions when investing in stocks in the capital market.

The results of this study can provide an overview to stock investors about the importance of understanding financial literacy in investing in stocks. Investors with a high level of education cannot affect the effectiveness of the investments made, but when investors have a high level of education and understand financial literacy, it will cause investors to be more effective in making stock investment decisions. Investors who have a high level of education and have a good level of financial literacy will be more considerate of risks, concepts, knowledge and understanding of finance which will make investors able to prevent or avoid possible risks of loss in investing in stocks such as capital loss. In addition, by understanding financial literacy, investors will be able to obtain benefits such as more optimal capital gains so that the role of financial literacy in stock investment will be very important to optimize profits and minimize the risks of losses that may occur.

Based on the results of this study, it was found that financial literacy is able to mediate the influence of education on investment decisions so that investors who want to invest in stocks, apart from having a high level of education, should also have good financial literacy. Having a good level of financial literacy will make investors able to consider risks, concepts, knowledge and understanding of finance which will later enable investors to prevent or avoid possible risks of loss in investing in stocks so that the profits obtained will be more optimal.

This research is limited to examining the role of financial literacy in mediating the influence of sociodemographic on investment decisions, further research is expected to be able to add other 


\section{International Journal of Business Management and Economic Review}

Vol. 4, No. 04; 2021

ISSN: 2581-4664

variables that are also able to strengthen the financial system and improve people's welfare so that research will be more recent. Further research is also expected to be able to add other sociodemographic factors such as marital status, occupation, years of service and other demographic factors so that it will make the research more interesting to study.

\section{REFERENCES}

Abdeldayem, M. M. 2016. Is there a relationship between financial literacy and investment decisions in the kingdom of Bahrain?. Journal of Management and Accounting Studies, Vol. 4, No. 2, pp. 68-78.

Adam, A. M., Boadu, M. O., \& Frimpong, S. 2018. Does Jenis kelamin disparity in financial literacy still persist after retirement? Evidence from Ghana. International Journal of Social Economics, Vol. 45, No. 1, pp. 18-28.

Ahmadi, H., \& Sulistyowati, L. N. 2018. Pengaruh Status Sosial Ekonomi, Jenis kelamin Terhadap Financial literacy Studi Eksperimen Pada Pelaku Usaha UMKM di Madiun. In Prosiding Seminar Nasional SIMBIOSIS, Vol. 3, pp. 178-187.

Ajzen, I. 1991. The Theory of Planned Behavior. Organizational Behavior and Human Decision Processes, Vol.50, pp.179-211.

Akims, M. A., \& Jagongo, A. 2017. Financial Literacy and Its Impact on Investment Decisions in Nigeria: A Theoretical Perspective. International Journal of Scientific Research and Innovative Technology, Vol. 4, No. 11.

Akmal, H., \& Saputra, Y. E. 2016. Analisis tingkat Financial literacy. JEBI (Jurnal Ekonomi dan Bisnis Islam), Vol. 1, No.2, pp. 235-244.

Akoto, G. O., Appiah, K. O., \& Turkson, J. K. 2017. Financial literacy of cocoa farmers in Ghana. International Journal of Accounting and Finance, Vol. 7, No.1, pp. 11-30.

Ali, P., Anderson, M. E., McRae, C. H., \& Ramsay, I. 2016. The financial literacy of young people: Socio-economic status, language background and the rural-urban chasm. Australian and International Journal of Rural Education, Vol. 26, No. 1, pp. 54-66.

Alwahaibi, S. S. O. 2019. Is demographic information influence risk tolerance/aversion in investment decision? Evidences from literature review. International Journal of academic research in accounting, finance and management sciences, Vol. 9, No. 1, pp. 111-122.

Amaliyah, R \& Witiastuti, S. R. 2015. Analisis Faktor Yang Mempengaruhi Literacy Keuangan di Kalangan UMKM Kota Tegal. Mejemen Analisis Jurnal, Vol. 4, No. 3.

Andansari, P. I. 2018. Pengaruh Sikap Keuangan dan Lingkungan Sosial Terhadap Financial literacy Mahasiswa. Ecodunamika, Vol. 1, No. 1.

Aprea, C., Wuttke, E., Breuer, K., Koh, N. K., Davies, P., Greimel-Fuhrmann, B., \& Lopus, J. S. (Eds.). 2016. International handbook of financial literacy. Singapore: Springer.

Aren, S., \& Aydemir, S. D. 2015. The factors influencing given investment choices of individuals. Procedia-Social and Behavioral Sciences, Vol. 210, pp. 126-135.

Arianti, B. F. 2018. The influence of financial literacy, Perilaku Keuangan and income on investment decision. EAJ (Economics and Accounting Journal), Vol. 1, No. 1, pp. 1-10.

Aribawa, D., \& Widyatini, I. R. 2017. Creative Business Financial Literacy in Yogyakarta. International Journal of Social Science and Business, Vol. 1, No. 2, pp. 108-115.

Arikunto, S. 2010. Prosedur Penelitian Suatu Pendekatan Praktik. Jakarta: Rineka Cipta.

Arya, P. 2018. Financial literacy and financial education in India: An assessment. International 
International Journal of Business Management and Economic Review

Vol. 4, No. 04; 2021

ISSN: 2581-4664

Research Journal of Commerce Arts and Science, Vol. 9, No. 3, pp. 72-80.

Atkinson, A., \& Messy, F. 2012. Measuring financial literacy: results of the OECD/International Network on Financial Education (INFE). Pilot Study Working Paper. OECD Publishing. Retrieved on April 5, 2013.

Awais, M., Laber, M. F., Rasheed, N., \& Khursheed, A. 2016. Impact of financial literacy and investment experience on risk tolerance and investment decisions: empirical evidence from Pakistan. International Journal of Economics and Financial Issues, Vol. 6, No. 1.

Badan Pusat Statistik Provinsi Bali. 2020. Istilah Statistik. www.bps.go.id. Diakses pada tanggal 18 September 2020

Bhavani, G., \& Shetty, K. 2017. Impact of demographics and perceptions of investors on investment avenues. Accounting and Finance Research, Vol. 6, No. 2, pp. 198-205.

Buchanan, J \& Tullock, G. 1962. The Calculus of Consent. University of Michigan, Ann Arbor.

Bursa Efek Indonesia. 2021. Press Release:Tutup Tahun 2020 dengan Optimisme Pasar Modal Indonesia Lebih Baik. www.idx.co.id. Diakses pada tanggal 25 Juni 2021

Calamato, M. P. 2010. Learning financial literacy in the family. Unpublished master's thesis. The Faculty of the Department of Sociology, San José State University.

Chetanbhai, J. M., Desai, D., \& Dawood, M. 2016. Financial Literacy an Apparatus to Woman Empowerment. Global Journal of Research in Management, Vol. 8, No. 1, pp. 16-27.

Darmawan, A., \& Pratiwi, F. A. 2020. Pengaruh Pendidikan Keuangan Keluarga, Pembelajaran Keuangan di Perguruan Tinggi, Sikap Keuangan dan Teman Sebaya Terhadap Financial literacy Mahasiswa. Fokus Bisnis: Media Pengkajian Manajemen dan Akuntansi, Vol. 19, No. 1, pp. 27-37.

Departemen Kesehatan RI. 2009. Kategori Usia. Jakarta: Depkes RI.

Dewi, I. M., \& Purbawangsa, I. B. A. 2018. Pengaruh Literasi Keuangan, Pendapatan Serta Masa Bekerja Terhadap Perilaku Keputusan Investasi. E-Jurnal Ekonomi dan Bisnis Universitas Udayana, Vol. 7, No. 7, pp. 1867-1894.

Edwards, R., Allen, M. W., \& Hayhoe, C. R. 2007. Sikap Keuangans and family communication about students' finances: The role of sex differences. Communication Reports, Vol. 20, No. 2, pp : 90-100.

Ergün, K. 2018. Financial literacy among university students: A study in eight European countries. International journal of consumer studies, Vol. 42, No. 1, pp. 2-15.

Erner, C., Goedde-Menke, M., \& Oberste, M. 2016. Financial literacy of high school students: Evidence from Germany. The Journal of Economic Education, Vol. 47, No. 2, pp. 95-105.

Fahmi, Irham. 2011. Analisis Laporan Keuangan. Lampulo: ALFABETA

Faidah, F. 2019. Pengaruh literasi keuangan dan faktor demografi terhadap minat investasi mahasiswa. Journal of Applied Business and Economic, Vol. 5, No. 3, pp. 251-263.

Febriyani, I., \& Sari, R. C. 2017. Pengaruh Jenis kelamin dan Prestasi Akademik Terhadap Financial literacy Mahasiswa Pendidikan Akuntansi Angkatan 2014. Kajian Pendidikan Akuntansi Indonesia, Vol. 6, No. 4.

Garg, N., \& Singh, S. 2018. Financial literacy among youth. International journaL of social economics, Vol. 45, No. 1, pp. 173-186

Ghazali, M. S., Azer, I., Mohamad, S. A., Muhamad Arifin, N. A., \& Mat, A. 2017. Personal financial literacy among high school students in Raub Pahang, Malaysia. Journal of Engineering and Applied Sciences, Vol. 12, No. 7, pp. 1830-1834. 


\section{International Journal of Business Management and Economic Review}

Vol. 4, No. 04; 2021

ISSN: 2581-4664

Ghozali, Imam. 2016. Aplikasi Analisis Multivariate Dengan Program SPSS. Semarang: Badan Penerbit Universitas Diponegoro.

Gilarso, T. (2004). Pengantar ilmu ekonomi makro. Kanisius.

Grohmann, A. 2016. The Jenis kelamin gap in financial literacy: income, education, and experience offer only partial explanations. DIW Economic Bulletin, Vol. 6, No. 46/47, pp. 531-537.

Hair, J. F., Black, W. C., Babin, B. J., \& Anderson, R. E. 2010. Multivariate Data Analysis (Seventh Edition). Upper Saddle River: Pearson Education.

Hasan, M. 2017. Pendidikan Ekonomi Informal dan Financial literacy. Membangun Indonesia Melalui Riset.

Hastings, J., \& Mitchell, O. S. 2011. Financial literacy: implications for retirement security and the financial marketplace. Oxford, UK: Oxford University Press.

Hidajat, T. 2015. Literasi Keuangan. Jawa Tengah: STIE Bank BPD Jateng. Manajemen Teori dan Terapan.

Jacobsen, C., \& Correia, J. 2019. Analysis of Financial Literacy in a College Population. Journal of Higher Education Theory and Practice, Vol. 19,No. 4, pp. 11-18.

Jana, D., Sinha, A., \& Gupta, A. 2019. Determinants of Financial Literacy and Use of Financial Services: An Empirical Study amongst the Unorganized Sector Workers in Indian Scenario. Iranian Journal of Management Studies, Vol. 12, No. 4, pp. 657-675.

Janor, H., Yakob, R., Hashim, N. A., Zanariah, Z., \& Wel, C. A. C. 2017. Financial literacy and investment decisions in Malaysia and United Kingdom: A comparative analysis. Geografia-Malaysian Journal of Society and Space, Vol. 12, No. 2, pp. 106-118.

Jappelli, T. 2010. Economic literacy: An international comparison. The Economic Journal, Vol. 120, No. 548, pp.429-451.

Johnson, E., \& Sherraden, M.S. 2007. From financial literacy to financial capability among youth. Journal of Sociology and Social Welfare, Vol. 34, No.3, pp. 119-146.

Joseph, C. N. 2015. Illusion Of Control dan Faktor Demografi dalam Pengambilan Keputusan Investasi. Jurnal Ekonomi Peluang, Vol. 9, No. 2, pp. 108-117.

Khairiyati, C \& Krisnawati, A. 2019. Analisis Pengaruh Literasi Keuangan Terhadap Keputusan Investasi pada Masyarakat Kota Bandung. Almana: Jurnal Manajemen dan Bisnis, Vol. 3, No. 2, pp. 301-312.

Lee, Nancy R and Philip Kotler. 2011. Social Marketing : Influencing Behaviors for Good. US. Sage Publication, Inc.

Lestari, S. Y. 2020. Pengaruh Pendidikan Pengelolaan Keuangan Di Keluarga, Status Sosial Ekonomi, locus of control Terhadap Financial literacy (Pelajar SMA Subang). Prisma (Platform Riset Mahasiswa Akuntansi), Vol. 1,No. 2, pp. 69-78.

Liebowitz, J. (Ed.). 2016. Financial literacy education: Addressing student, business, and government needs. CRC Press.

Lie, L.R., \& Wiagustini, P.L.N. 2020. The Effect of Financial Literacy And Sociodemographic Factors On Millennial's Investment Decision-Making Behavior. SSRG International Journal of Economics and Management Studies, Vol. 7, No.7, pp.132-139.

Loke, Y. J. 2017. The influence of socio-demographic and Pengetahuan Keuangan factors on financial management practices of Malaysians. International Journal of Business and 
Society, Vol. 18, No. 1, pp. 33-50.

Lusardi, A., \& Mitchell, O. S. 2011. Financial literacy around the world: An overview. Journal of Pension Economics and Finance, 4, 497-508.

Mahapatra, M. S., \& Mehta, S. 2015. Behavioral finance: a study on gender based dilemma in making investment decisions. SUMEDHA Journal of Management, Vol. 4, No. 1, pp. 4-16.

Margaretha, F., \& Pambudhi, R. A. 2015. Tingkat Financial literacy pada mahasiswa S-1 fakultas ekonomi. Jurnal Manajemen dan Kewirausahaan, Vol. 17,No. 1, pp. 76-85.

Monticone, C. 2010. How much does wealth matter in the acquisition of financial literacy?. The Journal of Consumer Affairs, Vol. 44, No.2, pp : 403-422.

Mouna, A., \& Anis, J. 2017. Financial literacy in Tunisia: Its determinants and its implications on investment behavior. Research in International Business and Finance, Vol. 39, pp. 568577.

Nababan, D., \& Sadalia, I. 2012. Analisis Personal Financial Literacy dan Perilaku Keuangan Mahasiswa Strata I Fakultas ekonomi Universitas Sumatera Utara

Natoli, R. 2018. Factors contributing to financial literacy levels among a migrant group. International Journal of Social Economics, Vol. 45, No. 1, pp. 173-186.

Nitisusastro, Mulyadi. 2012. Perilaku Konsumen dalam Perspektif Kewirausahaan. Bandung : Alfabeta

OECD. 2013. Set of criteria, principles, guidelines and policy guidance to improve financial education: Part 3 Measurement and evaluation tools. Paris: OECD

OECD. 2018. Financial Inclusion And Consumer Empowerment In Southeast Asia. Paris: OECD

Otoritas jasa keuangan. 2013. Literasi Keuangan Indonesia. www.ojk.go.id. Diakses pada tanggal 25 Juni 2021

Otoritas Jasa Keuangan. 2020. Indonesian National Strategy For Financial Literacy. www.ojk.go.id.

Otoritas Jasa Keuangan. 2020. Strategi Nasional Financial literacy Indonesia (Revisit 2017). www.ojk.go.id.

Potrich, A. C. G., Vieira, K. M., \& Kirch, G. 2015. Determinants of financial literacy: Analysis of the influence of socioeconomic and demographic variables. Revista Contabilidade \& Finanças, Vol. 26, No. 69, pp. 362-377.

Potrich, A. C. G., Vieira, K. M., \& Kirch, G. 2018. How well do women do when it comes to financial literacy? Proposition of an indicator and analysis of Jenis kelamin differences. Journal of Behavioral and Experimental Finance, Vol. 17, pp. 28-41.

Prasad, H., Meghwal, D., \& Dayama, V. 2018. Digital Financial Literacy: a Study of Households of Udaipur. Journal of Business and Management, Vol. 5, pp. 23-32.

Putri, N. M. D. R., \& Rahyuda, H. 2017. Pengaruh tingkat financial literacy dan faktor sosiodemografi terhadap perilaku keputusan investasi individu. E-Jurnal Ekonomi dan Bisnis Universitas Udayana, Vol. 6, No. 9, pp. 3407-3434.

Putri, R. A., \& Isbanah, Y. 2020. Faktor-Faktor yang Mempengaruhi Keputusan Investasi pada Investor Saham di Surabaya. Jurnal Ilmu Manajemen (JIM), Vol. 8, No. 1, pp. 197-209.

Putri, W. W., \& Hamidi, M. 2019. Pengaruh literasi keuangan, efikasi keuangan, dan faktor demografi terhadap pengambilan keputusan investasi (studi kasus pada mahasiswa magister manajemen fakultas ekonomi universitas andalas padang). Jurnal Ilmiah Mahasiswa Ekonomi Manajemen, Vol. 4, No. 1, pp. 210-224. 


\section{International Journal of Business Management and Economic Review}

Vol. 4, No. 04; 2021

ISSN: 2581-4664

Rahman, M., \& Gan, S. S. 2020. Generation Y investment decision: an analysis using behavioural factors. Managerial Finance. Vol. 46 No. 8, pp. 1023-1041.

Sabri, N. A. A., \& Afiqah, N. 2016. The relationship between the level of financial literacy and investment decision-making millennials in Malaysia. A Contemporary Business Journal, Vol. 6, pp. 39-47.

Santoso, S. B. 2016. Analisis Faktor-Faktor yang Mempengaruhi Keputusan Investasi Tenaga Kerja Indonesia (Studi kasus Desa Arjowilangun Kecamatan Kalipare Kabupaten Malang). Jurnal Ilmiah Mahasiswa FEB, Vol. 4, No. 1.

Sekaran, U., \& Bougie, R. 2016. Research Method for Business (7th ed.). Chichester, West Sussex,: Printer Trento Srl.

Shakirah, A., Shafik. M., \& Ahmad, W. M. W. 2020. Financial literacy among Malaysian Muslim undergraduates. Journal of Islamic Accounting and Business Research, Vol. 11, No. 8, pp. 1515-1529.

Sholihin, M., \& Ratmono, D. 2013. Analisis SEM-PLS dengan WarpPLS 3.0 untuk Hubungan Nonlinier dalam Penelitian Sosial dan Bisnis (I). Yogyakarta: ANDI.

Soekanto, Soerjono. 2013. Sosiologi Suatu Pengantar. Rajawali Pers: Jakarta

Sofia, N., \& Irianto, A. 2016. Pengaruh pendapatan orang tua, kelompok acuan, dan hasil belajar ekonomi terhadap Financial literacy mahasiswa fakultas ekonomi Universitas Negeri Padang. Jurnal Kajian Pendidikan Ekonomi, Vol. 3,No. 1, pp. 2-18.

Solimun, Achmad, Adji. R. F, Nurjannah. 2017. Metode Statistika Multivariat Pemodelan Persamaan Struktural (SEM) Pendekatan WarpPLS. Malang : UB Press.

Sommer. 2011. The Theory of Planned Behavior and Impact of Past Behavior. The International Business and Economics Research Journal, Vol. 10, No. 1.

Son, J., \& Park, J. 2019. Effects of financial education on sound personal finance in Korea: Conceptualization of mediation effects of financial literacy across income classes. International Journal of Consumer Studies, Vol. 43, No. 1, pp. 77-86.

Stella, G. P., Filotto, U., Cervellati, E. M., \& Graziano, E. A. 2020. The Effects of Financial Education on Financial Literacy in Italy. International Business Research, Vol. 13, No. 4, pp. 1-44.

Sugiyono. 2013. Metode Penelitian Bisnis. Jakarta: PT. Gramedia Pustaka. Utama.

Suryanto \& Rasmini, M. 2018. Analisis Literasi Keuangan dan Faktor-Faktor yang Mempengaruhinya. Jurnal Ilmu Politik dan Komunikasi, Vol. 8, No. 2.

Syuliswati, A. 2020. Pendidikan Pengelolaan Keuangan Keluarga, Gaya Hidup, Pembelajaran

Serta Pengaruhnya Terhadap Financial literacy. Akutansi Bisnis \& Manajemen (ABM), Vol. 27, No. 1, pp. 53-64.

Tandelilin, Eduardus. 2010. Portofolio dan Investasi Teori dan Aplikasi. Edisi pertama. Yogyakarta : Kanisius.

Tanusdjaja, H. 2018. Keputusan Investasi Investor Individu Berdasarkan Kompetensi, Overconfidence, Dan Pendidikan. Jurnal Muara Ilmu Ekonomi Dan Bisnis, Vol. 2, No. 1, pp. 234-244.

Tradingview. 2021. www.tradingview.com. Diakses pada tanggal 25 Juni 2021.

Upadana, I. W. Y. A., \& Herawati, N. T. 2020. Pengaruh Literasi Keuangan dan Perilaku Keuangan Terhadap Keputusan Investasi Mahasiswa. Jurnal Ilmiah Akuntansi dan Humanika, Vol. 10, No. 2, pp. 126-135. 
Vol. 4, No. 04; 2021

ISSN: 2581-4664

Vijayvargy, L., \& Bakhshi, P. 2018. Financial Literacy and Financial Inclusion in Rajasthan, India: An Empirical Study. IUP Journal of Applied Finance, Vol. 24, No. 3, pp. 35-53.

Violeta, J., \& Linawati, N. 2019. Pengaruh Anger Traits, Anxiety Traits, Dan Faktor Demografi Terhadap Keputusan Investasi. Jurnal Manajemen Pemasaran, Vol. 13, No. 2, pp. 89-96.

Wiagustini, Luh Putu. 2014. Dasar-dasar Manajemen Keuangan. Denpasar : Udayana University Press.

Widodo, R. M. P. 2016. Pengaruh Keputusan Investasi, Pendanaan dan Kebijakan Dividen terhadap Nilai Perusahaan. Jurnal Ilmu Riset Akuntansi. Vol. 5, No. 1, pp: 2460-0585.

Wiharno, H. 2017. Karakteristik Sosial Ekonomi yang Mempengaruhi Financial literacy serta Dampaknya terhadap Manajemen Keuangan Personal (Survei Pada Pegawai Negeri Sipil Daerah di Kabupaten Kuningan). Jurnal Riset Keuangan Dan Akuntansi, Vol. 1, No. 2, pp. $1-15$.

Wijayanti, W., Agustin, G., \& Rahmawati, F. 2016. Pengaruh Jenis kelaminn, IPK, dan Semester Terhadap Financial literacy Mahasiswa Prodi S1 Ekonomi Pembangunan Universitas Negeri Malang. Jurnal Pendidikan Ekonomi, Vol. 9, No. 1, pp. 88-98.

Winstanley, M., Durkin, K., Webb, R. T., \& Conti-Ramsden, G. 2018. Financial capability and functional financial literacy in young adults with developmental language disorder. Autism \& developmental language impairments, Vol.3, pp. 1-11

Xiao, J. J., \& O'Neill, B. 2016. Consumer financial education and financial capability. International Journal of Consumer Studies, Vol. 40, No. 6, pp. 712-721.

Yoshino, N., Morgan, P. J., \& Trinh, L. Q. 2017. Financial literacy in Japan: Determinants and impacts. ADBI working paper series, No. 796.

Yunita, N. 2020. Pengaruh Jenis kelamin dan Kemampuan Akademis Terhadap Financial literacy Dalam Perilaku Pengelolaan Keuangan Pada Mahasiswa Jurusan Akuntansi. Prisma (Platform Riset Mahasiswa Akuntansi), Vol. 1, No. 2, pp. 1-12.

Zhang, H., \& Xiong, X. 2019. Is financial education an effective means to improve financial literacy? Evidence from rural China. Agricultural Finance Review, Vol. 80, No. 3, pp. 305-320 